Article

\title{
Sustainability Aspects of Real Estate Development: Lithuanian Case Study of Sports and Entertainment Arenas
}

\section{Rasa Apanavičienė ${ }^{1}$, Ala Daugèlienė ${ }^{1}$, Tautvydas Baltramonaitis ${ }^{1}$ and Vida Maliene ${ }^{2,3, *}$}

1 Faculty of Civil Engineering and Architecture, Kaunas University of Technology, Studentų Str. 48, LT-51367 Kaunas, Lithuania; E-Mails: rasa.apanaviciene@ktu.lt (R.A.); ala.daugeliene@ktu.lt (A.D.); tautvydas.baltramonaitis@ktu.lt (T.B.)

2 School of the Built Environment, Liverpool John Moores University, Byrom Street, L3 3AF Liverpool, UK

3 Institute of Land Management and Geomatics, Faculty of Water and Land Management, Aleksandras Stulginskis University, Universiteto 10, Akademija, Kaunas 53361, Lithuania

* Author to whom correspondence should be addressed; E-Mail: v.maliene@1jmu.ac.uk; Tel.: +44-(0)-151-231-2854.

Academic Editor: Marc. A. Rosen

Received: 25 March 2015 / Accepted: 15 May 2015 / Published: 26 May 2015

\begin{abstract}
The principles of sustainability have become particularly important in the real estate and construction sector over the past decade. Despite extended efforts to evaluate the sustainability aspects of the real estate development, very few attempts have been exposed in the scientific literature pursuing integrating the investors and real estate developers' responsibility for the local community, regional economy and environmental problems within their financial expectations. The paper presents methodology enabling evaluating the balance of real estate development sustainability and financial viability issues during the feasibility study process. The Model for Real Estate Investment Evaluation Based on Sustainable Development Aspects proposed by the authors was applied to the case study of Lithuanian sports and entertainment arenas. By using multi-criteria decision analysis sustainability assessment of multi-functional arenas was carried out which disclosed that positive sustainability effects lays down on the owner's and operator's monetary liabilities.
\end{abstract}

Keywords: sustainable development; real estate; model; sports arenas; multi-criteria decision analysis 


\section{Introduction}

Sustainable properties are one of the key issues and challenges for today's construction and real estate (RE) industry over the world. Requirements for energy consumption and environmental protection, contribution for regional economies and communities, and social responsibility force necessary changes to be undertaken by real estate owners and developers. New strategic thinking, as well as advanced approaches and practices need to be adopted by researches, planners, practitioners and professionals within real estate society in order to create more value for the clients of today and future generations.

The Lithuanian real estate market was known as relatively small and very local a few years ago; however, the situation has been changed recently. The Lithuanian economy is demonstrating fast recovery from the crisis of the year 2009-2010. GDP increased by $2.9 \%$ in 2014 and 3.4\% in 2013. Analysts are predicting growth of $2.3 \%-2.7 \%$ in 2015 and $3.2 \%-3.5 \%$ growth in 2016 . Average annual rate of inflation dropped from $1.2 \%$ in 2013 to $0.2 \%$ in 2014. Consumer Price Index (CPI) growth of $0.5 \%-1.0 \%$ is expected in 2015 [1].

The improving economic situation has been reflected in the Lithuanian real estate market activity as well as the construction industry. The total volume of investment through purchasing already developed commercial property has been growing rapidly. After an investment breakthrough in 2013, 18 investment transactions (modern office, retail and industrial property worth over 1.5 million EUR) were registered in Lithuania, with a total value of 204 million EUR; 30\% more than 2013. In total, 99,200 $\mathrm{m}^{2}$ of offices, $55,600 \mathrm{~m}^{2}$ of retail premises and 22,200 $\mathrm{m}^{2}$ of warehousing/industrial premises have been purchased in 2014 [2]. Lithuania adopted the euro as its national currency on 1 January 2015, becoming a member of the euro zone and opening opportunities to new investors. In the beginning of 2015, the largest real estate transaction in the Baltic States since the crisis was successfully closed. The total transaction value amounted to 163 million EUR [3].

Real estate development, both in Lithuania and around the world, is facing the twenty-first century urban challenges - responsible use of energy resources, sustainable urban development within existing neighborhoods, comprehensive renovation and construction of new buildings, decreasing social exclusion, public transport development, and reduction of pollution - all of which should be implemented in the real estate development projects. These processes have impacts on the real estate business, as sustainable urban development is the backbone of the economy and the future of the real estate market. Thus, it is equally important to identify the trends and predict the directions of further real estate development. Whilst sustainable development regulation for the EU Member States is increasingly being driven by EU legislation, the methodologies for sustainable properties assessment have been developed based on indicators and measures at the individual country level: certification system developed by Austrian Society for Sustainable Real Estate in accordance with the German Sustainable Building Council ÖGNI/DGNB (Österreichische Gesellschaft für Nachhaltige Immobilienwirtschaft /Deutsche Gesellschaft für Nachhaltiges Bauen) in Austria, certification system for sustainable buildings DGNB/BNB (Deutsche Gütesiegel Nachhaltiges Bauen/Bewertungssystem Nachhaltiges Bauen) in Germany, Building Research Establishment Environmental Assessment Method (BREEAM) in United Kingdom, Leadership in Energy and Environmental Design (LEED) in USA, sustainability rating system Green Star in Australia, Comprehensive Assessment System for Built Environment Efficiency (CASBEE) in Japan, certification system for low energy consumption buildings MINERGIE ECO in 
Switzerland, High Quality Environmental standard (HQE) in France, Protocol ITACA (developed by ITACA - the Italian Conference of Regions and Autonomous Provinces) in Italy, building performance assessment system SBTool in Canada, etc. [4-9]. The above-mentioned national certification systems are created to meet the legal regulations and requirements of the specific country, however few of these tools-LEED introduced by US Green Building Council (USGBC, 2001) and BREEAM introduced by the British Research Establishment Limited (BRE, 1998) have been proven by long-term worldwide application practice. Despite that, in Lithuania there are no buildings certified according to BREEAM, LEED, or any other sustainability certification system [10]. The problem for the future investors is to find the properties in Lithuania that might be considered sustainable. In regard to the environmental sustainability aspect, there are two obligatory issues in Lithuania. According to the Law on Environmental Impact Assessment of the Proposed Economic Activity, the assessment on the environmental impact is required only for projects for a certain type economic activities: "The object of environmental impact assessment shall be the proposed economic activity which, by virtue of its nature, size or location, may have a significant effect on the environment. This activity shall be included in: (1) the List of the proposed economic activities subject to an environmental impact assessment (2) the List of the proposed economic activities subject to screening for an environmental impact assessment" [11]. The Law on Construction establishes all essential requirements for construction works that are being built, reconstructed and repaired within the territory of the Republic of Lithuania, and the minimum requirements for energy performance of buildings. Energy performance certificate has to be issued for new buildings and existing buildings before real estate transaction [12].

In regard to the social and economic aspect, there is a requirement to assess the financial and social-economic benefits of investment projects sponsored by public and EU funds, but there was no legal enforcement to assess the different project development options until 2015. The new legislation was issued by the Ministry of Finance of Republic of Lithuania on 31 December 2014, which is targeted to justify the public money expenditure for new real estate development [13]. Additionally to this, the quality assessment methodology for project optimal alternative selection for projects exceeding investment value of 300,000 EUR was approved on 14 October 2014 [14]. The minimum required options need to be assessed and compared from the financial and socio-economic perspective in case of the new real estate development are the following:

(1) construction of new buildings;

(2) distance service for project target groups;

(3) reconstruction/conversion of the existing property;

(4) rent/ lease of property; and

(5) acquisition of a new property.

However, as can be seen from this list of minimum required options, there is no obligation to analyze the various design, construction and operation alternatives in order to prove the new project's sustainability. Thus, there has been no methodology provided for the new real estate development sustainability assessment by the authorities in Lithuania.

This research paper addresses this gap by presenting the Model for Real Estate Investment Evaluation Based on Sustainable Development Aspects. The model is recommended to be used by private and public investors for the evaluation of the future real estate development project sustainability. This approach 
will also enable to raise awareness amongst owners, occupants and investors to carry out the whole life-cycle analysis of the project in order to justify the design, construction and operation solutions while preparing the feasibility study of new real estate development.

\section{Methodology for Real Estate Investment Evaluation Based on Sustainable Development Aspects}

"The results of the international and in particular the European standardization activities have led in recent years to the development of a unified understanding of sustainability in construction" [15]. Significant contributions were provided by the ISO TC 59 SC 17 and CEN TC 350 projects [16,17]. Numerous reports were published by the United Nations Environment Programme Finance Initiative (UNEP FI), the Royal Institution of Chartered Surveyors (RICS), SuPerBuildings and OPEN HOUSE projects were developed under European Community's Seventh Framework Programme, etc. Based on the provided guidelines and methodologies for the sustainability assessment, the following sustainable development priorities have to be incorporated into the assessment framework of real estate development, namely: harmonized economy development of different industry branches and regions, reduction of economic and social disparities between regions, environmental protection and efficient use of natural resources; waste management; healthcare; increasing employment of population; decreasing poverty, unemployment, social exclusion; etc. [17-23]. The above-mentioned aspects in real estate terms are considered to decrease operating costs, use of land, natural resources and emissions; increase energy efficiency, population healthcare and quality of life; as well as preservation of the cultural value of the buildings and extension of the operation period. According to UN-supported Principles for Responsible Investment (PRI) "responsible investment is an approach to investment that explicitly acknowledges the relevance to the investor of environmental, social and governance (ESG) factors, and the long-term health and stability of the market as a whole. It recognizes that the generation of long-term sustainable returns is dependent on stable, well-functioning and well governed social, environmental and economic systems" [24]. However, Zielenbach states that three levels of real estate development sustainability measurement have to be taken into consideration when analyzing sustainability from point of view of corporate responsibility [25]. The first level focuses on assessing internal issues - sustainable business case benefits for the real estate developers. The second concentrates on determining direct benefits for the clients of new real estate development. The third looks at how to measure a project's broader effects on the well-being of the community and neighborhoods, evaluating additional value for the city or region built environment.

Different researchers analyzed the particular levels and aspects of real estate development sustainability. A significant part of investigations is related with the sustainable urban development within the cities and regions [26-28]. The majority of them are devoted to the assessment of infrastructure projects sustainability [29-33]. The other significant part of the research analyzes sustainable office buildings or residential housing projects, industrial construction, etc. [34-36].

Some authors focus only on a particular aspect of sustainable development, like environmental assessment, projects impact on economic or social sustainability of the region, by identifying and analyzing assessment indicators [37-42]. Those who are trying to combine all three issues, provide the systematic approach or framework of sustainability indicators, which are recommended to be properly 
evaluated by project stakeholders and public decision makers [43-47]. Only a few authors have provided integrated sustainability assessment models, enabling front-end building evaluation [48-51].

Despite extended efforts to evaluate the sustainability aspects, very few attempts have been exposed in the scientific literature pursuing to integrate and balance the investors and real estate developers' responsibility for the local community, regional economy and environmental problems with their financial expectations.

Lützkendorf et al. identified three different approaches to property investment [52]:

- defensive property investment - investment practices that adhere to written law only, i.e., conventional mainstream property investment practice;

- responsible property investment-maximizing the positive effects and minimizing the negative effects of property ownership, management and development on society and the natural environment in a way that is consistent with investor goals and fiduciary responsibilities; and

- sustainable property investment - encompasses the goal of maximizing positive and minimizing negative effects, but it goes one significant step further, since the investor lays down appropriate conditions so that all his (or her) actions are aimed at being sustainable.

According to the author's conclusions, sustainable property investment is the least practiced among the three above-mentioned approaches. Thus, from the point of view of real estate developers and investors, whilst being sustainable, real estate investments need to be financially viable.

Deng et al. analyzed the financial viability of investments in energy efficiency and examined this issue from the Singaporean residential developer's perspective. The research revealed, that developers pay for almost all of the additional costs of energy efficiency during construction; however, they only share part of the benefits associated with such green investments. The authors found no evidence that the development of green housing can immediately and significantly improve corporate financial performance [53].

Trowbridge et al. underlined the health impacts of transportation, community development, and other construction projects, both positive and negative within the real estate industry. Communities efficiently advocate for real estate investment that best promotes their health and well-being. However, market incentives for innovation within the real estate industry make it more difficult for developers that successfully target health behaviors and outcomes in their projects to differentiate themselves competitively [54].

Rakshan et al. evaluated the sustainability aspect of improved building insulation by including the embodied energy and greenhouse gas (GHG) emissions associated with the full lifecycle of additional insulation materials in the overall sustainability balance sheet of the development. This study showed that, in the particular case of the residential built environment of Dubai and the prevailing local electric power source generation mechanisms, the environmental sustainability cost of adding the insulation levels required to significantly mitigate transmission losses is small in comparison to the operational GHG emissions saved by their application [55].

Investigation about portfolio greenness and the financial performance of real estate investment trusts (REITs) was published by Eichholtz et al. The investigation of 2000-2011 proved that "greenness of REITs is positively related to three measures of operating performance - return on assets, return on equity and the ratio of funds from operations to total revenue" [56]. However, authors documented, "that 
there is no significant relationship between the greenness of property portfolios and abnormal stock returns, suggesting that stock prices already reflect the higher cash flows deriving from investments in more efficient properties".

The sustainable land use issue and need in transformation of the role of the State and of corporate land owners role was reported in the study carried out by Knoeffell et al. The investigation was based on large empirical research results on huge urban development projects governed by models of public-private-partnerships. The article demonstrates lack of sustainability, which stem from corporate private land owners' decisions on concrete land uses, which are primarily driven by rapid profit interests [57].

Technical, financial, private partner selection and all three sustainability aspects were incorporated in the Model for effectiveness evaluation of public-private partnership (PPP) automobile road infrastructure construction projects developed by Rudžianskaitè-Kvaraciejienè et al. [58]. This study revealed that the effectiveness of PPP infrastructure projects from the private partner perspective depends on technical, financial and private partner's competence factors, and project sustainability metrics as well. The same tendency was identified for the public partner or sustainability perspective. The level of project sustainability is directly related not only to environmental, social and economic criteria, but also depends on technical and financial characteristics of the project as well as on the competence of the private partner, whose experience and risk management would guarantee the success and sustainability of the project.

Methods based on a single criterion can hardly be used in solving the problems associated with the complex environment of decision-making in selecting an appropriate option for investment. Therefore, the value and the utility degree of different alternatives for investment might be determined by implementation of Multi-Criteria Decision Making (MCDM) techniques.

There are numerous MCDM tools, which can be successfully applied for the decision-making within various sustainability issues. An analysis of MCDM methods and the observed advantages and disadvantages, as well as areas of application for each method was published by Velasquez and Hester [59]. MCDM methods were ranked based on their applicability and usage in various domains by Aruldoss et al [60]. Most widely applied methods in decision making problem were rated as follows: Technique for the Order Preference by Similarity to Ideal Solution (TOPSIS) - 30\% of all contributions, Fuzzy Analytic Hierarchy Process(AHP) - 20\% of all contributions, Elimination et Choix Traduisant la Realite (ELECTRE) - $16.67 \%$ of all contributions, Fuzzy MCDM-16.66\% of all contributions, Multicriteria Optimization and Compromise Solution VIKOR (from Serbian: VIseKriterijumska Optimizacija I Kompromisno Resenje $6.67 \%$ of all contributions and other methods have been applied in $10 \%$ of all contributions.

As the main MCDM tools used for environmental applications, three main approaches were indicated: Multi-Attribute Utility Theory (MAUT), Outranking approaches and Analytic Hierarchy Process (AHP) [61]. At the same time, other MCDM tools are widely used for the ranking of various management alternatives, such as TOPSIS, Simple Additive Weighting (SAW), Complex Proportional Assessment (COPRAS) and ELECTRE [62]. In particular, TOPSIS or fuzzy TOPSIS (TOPSIS-F) approaches have been successfully implemented for selecting resource-saving alternatives and ranking of economic decisions. However, according to the evaluation of different MCDM methods, and measuring objective congruence (incongruence) of the obtained results by these methods, priority to the results of COPRAS and TOPSIS methods should be given while treating economic and managerial 
issues [62]. Accordingly, multiple criteria evaluation results applying COPRAS and TOPSIS methods can be considered to be identical within the same probability.

By taking into consideration the priorities of future development perspectives broadly discussed in the scientific literature mentioned above, the authors of the paper developed the model that is recommended for real estate development sustainability assessment during the feasibility study process. The aim of the new model is to reveal systematic components affecting the development of sustainable built environment from real estate project idea formation to the end of the life cycle as well as to evaluate the overall investment effectiveness of real estate development in light of sustainable development. The model reflects the logic of real estate project development sequence (see Figure 1). Real estate development project concept stage refers to market research, objectives and constraints of building/ group of buildings and the urban area to be developed and improved by building(s). Fulfillment of technical and functional requirements and analysis of different architectural design options are incorporated into the formation stage of real estate development alternatives. In the sustainability assessment stage, real estate development alternatives are evaluated by using selected MCDM techniques. Criteria representing aspects of sustainable development reflect responsible investment principles and real estate development contribution to sustainable regional development. Depending on the object of assessment, criteria might be combined out of several specific sub-criteria that suit the project and regional characteristics. Life cycle cost analysis of the project is incorporated into financial analysis stage, as it helps to validate the project sustainability at the business case level. From the developer's point of view, real estate development alternatives have to prove the financial viability issues. If the sustainable real estate development alternative appears to be in line with the financial criteria (NPV, IRR, B/C, Payback period), it is selected for implementation.

The developed Model for Real Estate Investment Evaluation Based on Sustainable Development Aspects is presented in Figure 2. Practical employment of developed Model for Real Estate Investment Evaluation is introduced by the case study of multi-functional sports and entertainment arena investment assessment based on the aspects of sustainable development.

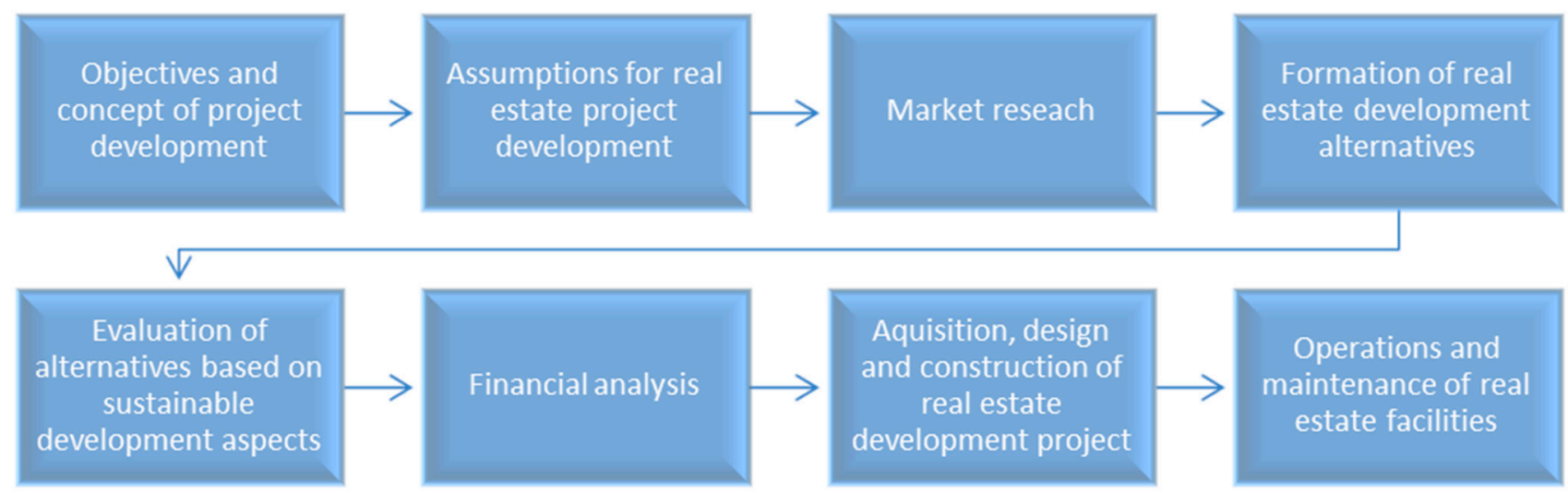

Figure 1. Stages of sustainable real estate project development. 


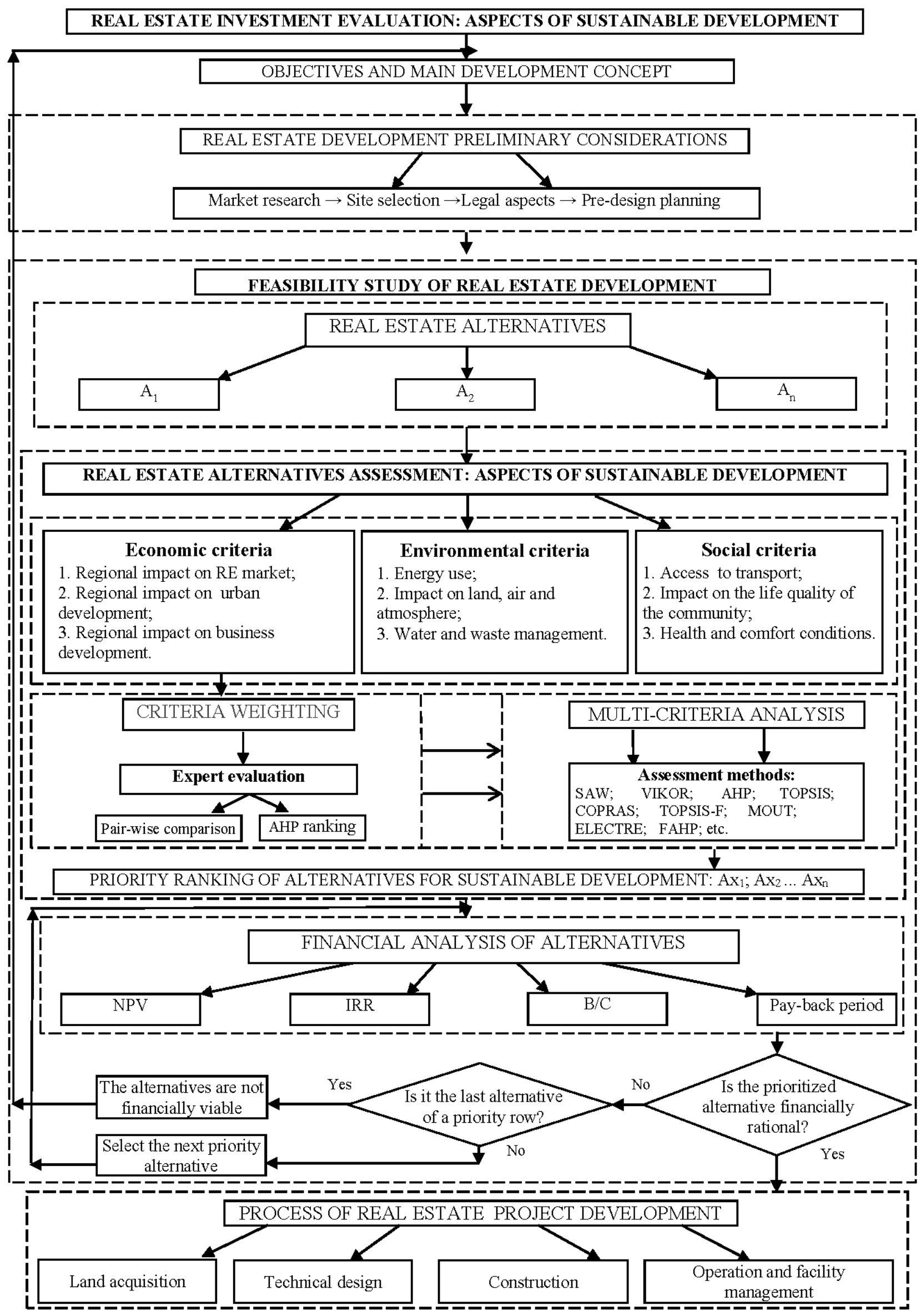

Figure 2. Model for real estate investment evaluation based on sustainable development aspects. 


\section{Lithuanian Case Study of Sports and Entertainment Arenas}

The investment of public money towards the building, renovating and maintaining of sports venues has regularly occurred over the past six decades [63]. Whilst some sports and entertainment venues can generate an operating profit, the economic returns from operation do not generally pay back the initial investment [64]. However, municipal and community governments have been subsidizing the construction of sports stadiums and arenas because they serve the public interest beyond purely financial goals, since they contribute to improving the quality of life, provide a potential for reviving the economy of a region, help to enhance their international reputation, and boost relevant industries and business sectors [65].

To identify the existing approach and practice in the assessment of multi-functional arena investment, a review of prevailing research focus areas was conducted, such as subsidization, economic and social impact of large-scale sports venues, and their sustainable facility management. The subsidization of professional sports facilities has inspired deeply contentious debates, as the opinion on the construction of new large-scale venues is one of the most controversial topics for observers of public policy. Existing research [66-68] focuses on identifying factors that induce voters to support or oppose plans for public funding of sports facilities, construction or renovation. Independent empirical analyses are often used to reject assertions that sports stadiums can serve as economic catalysts [69-71]. The broad conclusion of this literature is that stadiums and franchises are ineffective means for creating local economic development, whether that is measured as income or employment growth. However, in combination with consumer surpluses from venue attendance, subsidies may be efficient. Based on this information, municipal investment into sports venues should not be strictly looked at as a vehicle to produce economic returns, since sports facilities are, indeed, viable social anchors within communities and community networks $[63,72,73]$. Furthermore, they are capable of creating a preferred image for both community members and a fan nation.

Sustainable issues in multi-functional venues facility management are important since sports and entertainment facilities consume more resources and energy than typical, negatively impact the environment, and generate a large amount of waste. Therefore, the employment of sustainable facilities management strategies by using innovative energy-efficient technologies is also essential while evaluating various sports and entertainment venues [74-76].

\subsection{General Information about Lithuanian Multi-Functional Sports and Entertainment Arenas}

The case study investigates the selection of investment option within assessment of existing Lithuanian multi-functional arenas that provide not only financial efficiency for developers, but also comply with the major aspects of sustainable development - economic, environmental and social.

There are fourteen sports' arenas located in different cities and regional centers in Lithuania, which can be categorized as multi-functional sports and entertainment venues [77,78]. The establishment of venues has a positive impact on local economic development and urban landscape [79].

The majority of Lithuanian arenas are designed as universal halls for various sporting competitions, concerts, exhibitions, performances and other various cultural events and also serve as the home venue for local basketball teams [80-85]. Multi-functional arenas of the biggest cities-Zalgiris Arena of Kaunas city; Svyturys Arena of Klaipeda city; Cido Arena of Panevezys city; Arena of Alytus city; 
Arena of Siauliai city - were built within the period of 2007-2011 and hosted the European Basketball championship in 2011 [86]. Two arenas are individualized for their special features, such as 250-meter long Olympic cycling track in Cido arena [85] and the big skating rink in Vilnius Entertainment arena, formerly known as Vilnius Ice Palace [87].

Nine sports and entertainment venues were suggested and implicated in the case study assessment. In regards to seating capacity of multi-functional venues, the suggested arenas are presented in all major options: two large arenas with seating capacity over 10,000 seats, four average size arenas with capacity from 5000 to 10,000 seats and three small ones with capacity under 5000 seats. While the biggest cities arenas serve the population organizing the major sports and entertainment events, three Lithuanian multi-functional arenas (Alytus, Utena and Kedainiai arenas) are part of large sport complexes and host various sport schools and sport clubs, promoting youth sport activities $[86,88,89]$. Local municipalities hold the ownership rights for five multi-functional sports and entertainment venues: Zalgiris, Svyturys, Cido, Siauliai and Alytus arenas. Two arenas-Siemens Arena in capital city Vilnius rated as the second biggest arena in Lithuania built in 2002 and Vilnius Entertainment Arena built in 2004-are specified as private-owned; and one arena (Kedainiai Arena) was established by a private developer in 2013 and bestowed to the city of Kedainiai. Zalgiris arena is the most expensive arena, with a construction cost of 49 million EUR; then, Cido, Siauliai, Siemens, Svyturys, Alytus, Utena, Kedainiai and Vilnius Entertainment Arena with construction costs of 31 million EUR, 22 million EUR, 21 million EUR, 19 million EUR, 10 million EUR, 10 million EUR and 3 million EUR, respectively [77-80]. The range of general quantitative and comparative characteristics of sports and entertainment arenas incorporated in the case study is presented in Table 1.

Table 1. General characteristics of case study arenas.

\begin{tabular}{lcc}
\hline \multicolumn{1}{c}{ Criteria } & Min value & Max value \\
\hline Capacity for basketball, seats & 2200 & 15,688 \\
Capacity for concerts, seats & 3000 & 22,000 \\
Max number of visitors & 3044 & 17,000 \\
Number of service area residents & 26,080 & 523,050 \\
Number of annual events & 18 & 200 \\
Number of visitors per year & 50,000 & 500,000 \\
Construction costs, million EUR & 2.89 & 48.95 \\
State investments, million EUR & 0 & 35.42 \\
Investments of EU funds, million EUR & 0 & 12.88 \\
Private investment, million EUR & 0 & 16.22 \\
Annual municipality subsidies, million EUR & 0 & 0.72 \\
Cost per seat, EUR & 1158 & 5532 \\
Investment rate, EUR per resident & 19 & 1109 \\
\hline
\end{tabular}

Based on the theoretical assumptions and a study of existing practices, the set of indicators, with the help of which the aspects of sustainability can be assessed, is suggested and implicated in the evaluation of investment into sports and entertainment arenas. It is useful and preferable to keep separated social, environmental and economic performance of buildings [17]; therefore, proposed multi-functional venues are assessed with indicators comprising the three mentioned aspects of sustainability (see Table 2). 
Valuable information about indicators of sustainability and other parameters of suggested multi-functional arenas was gathered through surveys of arenas managers and operators carried out in 2014 and also obtained from publicly available information sources [77-89]. The set of selected sustainability indicators is presented in Table 2.

\subsection{Development of Criteria System for Multi-Functional Arenas Sustainability Assessment}

\subsubsection{Social Criteria for Multi-Functional Arenas Assessment}

The major social aspects, which are essential for multi-functional arena evaluation, were defined by the respondents of a survey conducted, and are integration into the urban spaces, accessibility, annual number of events, visitors' comfort conditions and implementation of innovative solutions for events performance. The operators' and managers' attempts and efforts to improve the living environment in the region and satisfy existing public demands were also taken into consideration. The suggested indicators of arena's social performance have been grouped and assigned to three sustainability criteria "accessibility of arenas", "number of visited events per resident" and "visitors' comfort conditions".

Accessibility of arena and visitors' comfort conditions are aggregated criteria, which represent the assessment by several social indicators taken into consideration. Accessibility of arenas stands for such indicators as distance from the city center, accessibility of arena by public and private transport, availability of additional transportation from event venue and duration of departure from arena. City residents as well as city visitors prefer it to be located in the city center, where the majority of public transport routes are available. Furthermore, parking should be located less than $25 \mathrm{~m}$ from the venue to make it more convenient for arena visitors. Generally, most sports and entertainments events take place late in the evening and are over when ordinary public transport has stopped running, therefore, the availability of public night routes or additional transportation from venue to various city areas is also essential. At the same time, the needs of visitors coming by private vehicles must also be met - there have to be enough parking spaces available and the possibility to enter and depart from parking place easily, thus avoiding additional air pollution in the city center due to traffic jams.

Another social criterion, "visitors' comfort conditions", reveals such performance indicators as significance of number and diversity of leisure zones, adaptability of arenas to different types of events, implemented innovative solutions for the events performance and types of chairs for spectators; it describes the level of comfort and convenience and the state of wellbeing of the multi-functional arena visitor. Most events take a long time and usually last several hours; therefore the feeling of physical comfort while sitting and observing the event is very important. To provide the spectators with a high-level event and its comfortable observation, exceptional acoustic technologies must be employed and advanced sound equipment installed; the arena spaces must be transformable in accordance with observation requirements for different events; and, finally, the chairs must be comfortable to prevent fatigue during long events. Diversity and availability of leisure zones is also relevant to the subject. 
Table 2. Multi-functional arenas' performance indicators.

\begin{tabular}{|c|c|c|c|c|c|c|c|c|c|c|}
\hline & \multirow{2}{*}{ Indicators } & \multicolumn{9}{|c|}{ Arenas } \\
\hline & & $\mathbf{X 1}$ & $\mathbf{X} 2$ & $\mathbf{X 3}$ & $\mathbf{X} 4$ & X5 & X6 & $\mathbf{X} 7$ & X8 & X9 \\
\hline \multirow{13}{*}{ 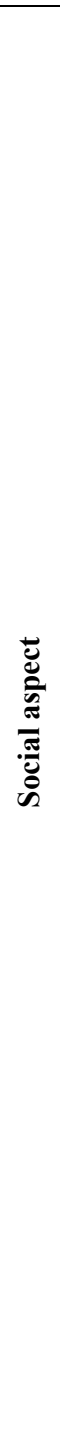 } & Distance from city center, $\mathrm{km}$ & 2 & 4 & 2 & 2 & 1 & 2 & 2 & 0 & 5 \\
\hline & Service area, $\mathrm{km}^{2}$ & 44 & 401 & 1229 & 52 & 42 & 81 & 110 & 157 & 401 \\
\hline & $\begin{array}{c}\text { Additional transportation } \\
\text { by public vehicle }\end{array}$ & Yes & No & No & No & No & No & Yes/No & Yes & No \\
\hline & $\begin{array}{c}\text { Number of available } \\
\text { parking places }\end{array}$ & 155 & 400 & 130 & 690 & 100 & 800 & 1500 & 1000 & 1650 \\
\hline & $\begin{array}{c}\text { Duration of departure by } \\
\text { private transport, } \min \end{array}$ & $10-20$ & $20-30$ & $10-20$ & $10-20$ & $10-20$ & $10-20$ & $10-20$ & $20-30$ & $20-30$ \\
\hline & Annual number of events & 60 & 18 & 200 & 70 & 40 & 60 & 75 & 90 & 100 \\
\hline & Annual number of visitors & 50,000 & 100,000 & 50,000 & 130,000 & 80,000 & 160,000 & 160,600 & 500,000 & 413,000 \\
\hline & $\begin{array}{c}\text { Number of annually } \\
\text { visited events per resident }\end{array}$ & 1.91 & 0.19 & 1.18 & 1.33 & 1.40 & 1.19 & 1.00 & 1.63 & 0.79 \\
\hline & Number of leisure zones & 6 & 3 & 2 & 10 & 2 & 9 & 10 & 21 & 22 \\
\hline & Diversity of leisure zones & $\begin{array}{l}\text { Café/restaurant } \\
\text { Smoking place }\end{array}$ & $\begin{array}{l}\text { Café/restaurant } \\
\text { Smoking place }\end{array}$ & $\begin{array}{l}\text { Café/restaurant } \\
\text { Smoking place }\end{array}$ & $\begin{array}{l}\text { Café/restaurant } \\
\text { Smoking place }\end{array}$ & $\begin{array}{l}\text { Café/restaurant } \\
\text { Smoking place }\end{array}$ & $\begin{array}{l}\text { Café/restaurant } \\
\text { Smoking place }\end{array}$ & $\begin{array}{l}\text { Café/restaurant } \\
\text { Smoking place }\end{array}$ & $\begin{array}{l}\text { Café/restaurant } \\
\text { Smoking place }\end{array}$ & $\begin{array}{l}\text { Café/restaurant } \\
\text { Smoking place }\end{array}$ \\
\hline & Adaptability to different events & $\begin{array}{c}\text { Space } \\
\text { transformation }\end{array}$ & $\begin{array}{c}\text { Space } \\
\text { transformation } \\
\text { Acoustic } \\
\text { adjustment }\end{array}$ & $\begin{array}{c}\text { Space } \\
\text { transformation }\end{array}$ & $\begin{array}{c}\text { Space } \\
\text { transformation } \\
\text { Acoustic } \\
\text { adjustment } \\
\text { Sound equipment }\end{array}$ & $\begin{array}{c}\text { Space } \\
\text { transformation }\end{array}$ & $\begin{array}{c}\text { Space } \\
\text { transformation } \\
\text { Acoustic } \\
\text { adjustment }\end{array}$ & $\begin{array}{c}\text { Space } \\
\text { transformation } \\
\text { Acoustic } \\
\text { adjustment }\end{array}$ & $\begin{array}{c}\text { Space } \\
\text { transformation } \\
\text { Acoustic } \\
\text { adjustment } \\
\text { Sound } \\
\text { equipment }\end{array}$ & $\begin{array}{c}\text { Space } \\
\text { transformation } \\
\text { Acoustic } \\
\text { adjustment } \\
\text { Sound } \\
\text { equipment }\end{array}$ \\
\hline & Type of chairs & Plastic & Soft & Plastic & Soft & Soft & Soft & Soft & Soft & Soft \\
\hline & $\begin{array}{l}\text { Innovative solutions for } \\
\text { performance of events }\end{array}$ & Scoreboard & $\begin{array}{c}\text { Multipurpose } \\
\text { flooring, } \\
\text { Ticketing }\end{array}$ & $\begin{array}{l}\text { Entrance, } \\
\text { Scoreboard }\end{array}$ & $\begin{array}{c}\text { Ticketing, } \\
\text { Entrance, } \\
\text { Scoreboard, } \\
\text { Information cube }\end{array}$ & $\begin{array}{l}\text { Entrance, } \\
\text { Scoreboard }\end{array}$ & $\begin{array}{l}\text { Multipurpose } \\
\text { flooring, } \\
\text { Entrance, } \\
\text { Scoreboard, } \\
\text { Information } \\
\text { cube }\end{array}$ & $\begin{array}{l}\text { Multipurpose } \\
\text { flooring, } \\
\text { Ticketing, } \\
\text { Entrance, } \\
\text { Scoreboard, } \\
\text { Information } \\
\text { cube }\end{array}$ & $\begin{array}{l}\text { Multipurpose } \\
\text { flooring, } \\
\text { Ticketing, } \\
\text { Scoreboard, } \\
\text { Information } \\
\text { cube }\end{array}$ & $\begin{array}{l}\text { Multipurpose } \\
\text { flooring, } \\
\text { Ticketing, } \\
\text { Scoreboard, } \\
\text { Information } \\
\text { cube }\end{array}$ \\
\hline
\end{tabular}


Table 2. Cont.

\begin{tabular}{|c|c|c|c|c|c|c|c|c|c|c|}
\hline & \multirow{2}{*}{ Indicators } & \multicolumn{9}{|c|}{ Arenas } \\
\hline & & $\mathbf{X} 1$ & $\mathbf{X} 2$ & $\mathbf{X 3}$ & $\mathrm{X} 4$ & X5 & X6 & $\mathbf{X} 7$ & X8 & X9 \\
\hline \multirow{8}{*}{ 芯 } & $\begin{array}{l}\text { Building energy } \\
\text { efficiency rating, class }\end{array}$ & $\mathrm{C}$ & $\mathrm{C}$ & $\mathrm{C}$ & $\mathrm{C}$ & $\mathrm{B}$ & $\mathrm{C}$ & $\mathrm{C}$ & $\mathrm{B}$ & B \\
\hline & $\begin{array}{c}\text { Specialist for } \\
\text { environmental protection }\end{array}$ & No & No & No & No & No & No & No & No & No \\
\hline & $\begin{array}{l}\text { BREEAM/LEED } \\
\text { certification }\end{array}$ & No & No & No & No & No & No & No & $\begin{array}{c}\text { Under } \\
\text { evaluation of } \\
\text { BREEAM } \\
\text { In-Use }\end{array}$ & No \\
\hline & Non-renewable energy & $\begin{array}{c}\text { Combined heat } \\
\text { and power }\end{array}$ & Electricity & $\begin{array}{c}\text { Combined } \\
\text { heat and } \\
\text { power }\end{array}$ & $\begin{array}{c}\text { Combined } \\
\text { heat and } \\
\text { power }\end{array}$ & $\begin{array}{c}\text { Combined } \\
\text { heat and } \\
\text { power }\end{array}$ & Electricity & Electricity & Electricity & Electricity \\
\hline & Renewable energy & No & No & No & No & No & No & No & No & No \\
\hline & Energy-saving measures & Water sources & $\begin{array}{c}\text { Recuperators, } \\
\text { El. sensors, } \\
\text { Low-energy } \\
\text { bulbs, Water } \\
\text { resources }\end{array}$ & $\begin{array}{c}\text { Recuperators, } \\
\text { Low-energy } \\
\text { bulbs, Water } \\
\text { sources }\end{array}$ & $\begin{array}{c}\text { Recuperators, } \\
\text { Low-energy } \\
\text { bulbs, Water } \\
\text { sources }\end{array}$ & $\begin{array}{c}\text { Recuperators, } \\
\text { Low-energy } \\
\text { bulbs, Water } \\
\text { sources }\end{array}$ & $\begin{array}{c}\text { Recuperators, } \\
\text { Low-energy } \\
\text { bulbs, Water } \\
\text { sources }\end{array}$ & $\begin{array}{c}\text { Recuperators, } \\
\text { El. sensors, } \\
\text { Low-energy } \\
\text { bulbs }\end{array}$ & $\begin{array}{c}\text { Recuperators, } \\
\text { El. sensors, } \\
\text { Low-energy } \\
\text { bulbs, Water } \\
\text { resources, } \\
\text { Energy } \\
\text { management }\end{array}$ & $\begin{array}{c}\text { Recuperators, } \\
\text { El. sensors, } \\
\text { Low-energy } \\
\text { bulbs, Water } \\
\text { resources }\end{array}$ \\
\hline & Waste tracking & No & Yes & No & Yes & Yes & Yes & No & Yes & Yes \\
\hline & Recycling & No & Yes & Yes & Yes & Yes & Yes & Yes & Yes & Yes \\
\hline
\end{tabular}


Table 2. Cont.

\begin{tabular}{|c|c|c|c|c|c|c|c|c|c|c|}
\hline & \multirow{2}{*}{ Indicators } & \multicolumn{9}{|c|}{ Arenas } \\
\hline & & $\mathbf{X} 1$ & $\mathbf{X} 2$ & $\mathbf{X 3}$ & $\mathrm{X} 4$ & X5 & X6 & $\mathbf{X} 7$ & X8 & X9 \\
\hline \multirow{8}{*}{ 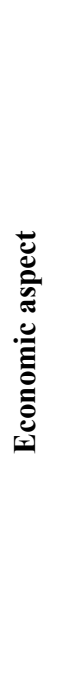 } & Investment rate, EUR per resident & 246 & 6 & 240 & 321 & 187 & 164 & 98 & 159 & 37 \\
\hline & State investments, $\%$ of the total & - & - & 100 & 35 & 49 & 35 & 37 & 72 & 17 \\
\hline & EU funds, $\%$ of the total & - & - & - & 65 & 51 & 65 & 63 & 28 & - \\
\hline & Private investment, $\%$ of the total & 100 & 100 & - & - & - & - & - & - & 83 \\
\hline & Number of full-time employees & 8 & 12 & 28 & 11 & 10 & 14 & 14 & 40 & 17 \\
\hline & Number of part-time employees & - & - & - & 50 & 20 & 25 & 30 & 300 & 100 \\
\hline & Income of non-core business, $\%$ & $>50$ & $>50$ & $0-10$ & $0-10$ & $0-10$ & $>50$ & $40-50$ & $20-30$ & $10-20$ \\
\hline & $\begin{array}{c}\text { Impact on urban } \\
\text { development within the area }\end{array}$ & $\begin{array}{c}\text { Landscape } \\
\text { development }\end{array}$ & $\begin{array}{l}\text { Shopping } \\
\text { malls, sport } \\
\text { complexes }\end{array}$ & $\begin{array}{c}\text { Environment/ } \\
\text { infrastructure, } \\
\text { sport and } \\
\text { leisure park }\end{array}$ & $\begin{array}{c}\text { Environment/ } \\
\text { infrastructure, } \\
\text { natural park }\end{array}$ & $\begin{array}{c}\text { Environment/ } \\
\text { infrastructure, } \\
\text { sport } \\
\text { complex, } \\
\text { natural park, } \\
\text { restaurants }\end{array}$ & $\begin{array}{c}\text { Environment/ } \\
\text { infrastructure, } \\
\text { natural park }\end{array}$ & $\begin{array}{l}\text { Environment/ } \\
\text { infrastructure, } \\
\text { shopping mall }\end{array}$ & $\begin{array}{c}\text { Environment/ } \\
\text { infrastructure, } \\
\text { shopping } \\
\text { mall, natural } \\
\text { park }\end{array}$ & $\begin{array}{c}\text { Leisure park: } \\
\text { Aqua park, } \\
\text { shopping } \\
\text { mall, natural } \\
\text { park }\end{array}$ \\
\hline
\end{tabular}


Employment of innovative technologies during the construction and operation periods is one of the factors reflecting the level of comfort and convenience; thus, it is quite essential to be outlined as social indicator. Modern entrance and ticketing systems provide easier and faster access to arenas for visitors; this, along with information panels and even information cubes, are the best solutions for observation of sports competitions. Multipurpose flooring system gives visitors the chance to observe a wide variety of events (e.g., both on parquet and ice).

Annual number of events indicates the demand in arena regarding its capabilities and location. The suggested arena alternatives are located in different cities; therefore the events and provided activities differ, while there is different population and demand for such events. Big number of organized events shows the capabilities of arena to meet the needs of citizens in leisure and entertainment activities. The criteria "number of visited events per resident" is an attribute, expressed by the means of ratio of performed events number and city's population, which indicates the number of events per city's resident.

\subsubsection{Environmental Criteria for Multi-Functional Arenas Assessment}

As essential environmental aspects for multi-functional arena evaluation, energy efficiency class of facility, "in-house" expert for environmental protection, BREEAM or LEED certification, type of energy used, and application of energy saving, waste-tracking, and recycling techniques were accentuated. These environmental indicators have been assigned to three environmental criteria "building energy efficiency", "environmental impact of arena's activities" and "employment of innovative technologies during construction and operation".

The first environmental criterion to be evaluated is the "building energy efficiency". Multi-functional arenas with the highest energy efficiency class get the best evaluation. "Impact on the environment" (noise, air pollution, waste, etc.) is another important environmental criterion. Environmental impact of arena's activities aggregates the points in regard to such indicators as available specialist for environmental protection, BREEAM/LEED certification and sources for energy used by arenas. Multi-functional sports and entertainment arenas consume relatively large amounts of electricity, to be supplied within employed equipment (lighting, sound equipment, etc.); also, facilities require intense heating and ventilation processes. Therefore, for the environmental assessment of arenas activities, it is essential to examine how the processes are carried out, whether buildings are equipped with recuperative energy systems and how they are used. It is also necessary to assess whether the arena managers are trying to reduce the negative environmental impact by using renewable energy sources.

The environmental criterion "employment of innovative technologies during construction and operation" shows how the suggested arenas implement various energy-saving, water and waste management measures. Due to high-energy consumption, arenas have correspondingly high direct and indirect negative effects on the environment (air pollution). Consequently, it is important to know if suggested arenas are subjected to any of energy-saving techniques, such as heat recuperators, electrical sensors, informative badges, low-energy light bulbs and water resources. Many arena visitors leaves behind significant amounts of waste, both direct (mostly food packaging) and indirect (e.g., cleaning after the event). It is important to find out whether the arena managers are trying to apply any waste tracking and reducing measures; and if not, whether the waste in arenas is sorted. 


\subsubsection{Economic Criteria for Multi-Functional Arenas Assessment}

While assessing the suggested arenas alternatives according to the economic aspects of sustainability, the greatest consideration should be made to the investment rates, impact on urban development as well as boosting relevant industries and business sectors. Consequently, three economic criteria were selected: "investment rate", "impact on relevant business" and "impact on urban development".

Investment rate shows the total amount of investment, including state, EU funds and private money, per resident. Development of the large-scale venues involves intensive capital investment and long-term operational expenses. It is a common practice in Lithuania that a multi-functional arena is built using public money; for this reason, it is extremely important that the costs are as low as possible. Additionally, municipal and community governments subsidize the construction of some multi-functional arenas because they expect the evidence for positive welfare effects on the environment as well as social benefits. Therefore, the best evaluation should be given to the arena, in which the public and private investment is the lowest.

Arenas cannot only perform its direct function to city's residents and visitors, e.g., to be the venue of event, but also provide additional services, such as catering, health, business and relevant industries. Arenas can be useful not only during concerts or other events; but can also generate additional income from commercial activities, which is a positive indicator in determining the effective use of the building itself. By improvement of the financial situation of city residents, the economic level of the city increases, respectively. The criterion "impact on relevant business" features incomes from non-core business and development of relevant business sectors and number of jobs created for both core and non-core activities. At the same time, the establishment of such sport and entertainment facilities has a positive impact on the urban development, while contributing to the improvement of landscape and creating modern infrastructure. The criterion "impact on urban development within the area" covers various aspects of landscape development, potential for the future urban structure expansion, and improvement related to the establishment of suggested arenas.

\subsection{Evaluation Criteria System for Investment into Multi-Functional Arenas}

In regard to the experts' opinion in the conducted survey, and according to the evaluation of suggested multi-functional venues alternatives, the set of criteria combining social, environmental and economic aspects was developed. The generated criteria system, together with alternative rates, is presented in Table 3. All criteria are expressed either by the ratio or by points in accordance with established point system. The major part of criteria is aggregated attributes, combining few different performance indicators, reflecting appropriate aspect of sustainable development.

The scoring of such aggregated criteria was defined as the summarized performance of particular set of suggested performance indicators combined into general criteria. Consequently, the highest ranking (9-10 points) scores were assigned to the aggregated criteria of suggested alternatives, which demonstrated integrated value higher than $2 / 3$ of the best performance value within the set of incorporated initial criteria; the middle ranking (7-8 points) scores were assigned to the alternatives attributing the range between the $2 / 3$ and $1 / 3$ of the best available performance value within the particular set of incorporated criteria; and the lowest ranking (5-6 points) scores were assigned to the criteria of 
alternatives demonstrated lower values than $1 / 3$ of the best performance value within the particular set of combining criteria. A score of 5 points stands for minimal acceptable assessment value in accordance to the compulsory requirements of technical and legal regulations.

Table 3. Criteria system for evaluation of investment into multi-functional arenas.

\begin{tabular}{|c|c|c|c|c|c|c|c|c|c|}
\hline \multirow{2}{*}{ Evaluation criteria } & \multicolumn{9}{|c|}{ Arenas } \\
\hline & $\mathrm{X} 1$ & $\mathrm{X} 2$ & $\mathbf{X} 3$ & $\mathrm{X} 4$ & X5 & X6 & $\times 7$ & X8 & X9 \\
\hline $\begin{array}{c}\text { Accessibility of arenas, } \\
\text { points }[5,10]\end{array}$ & 9 & 6 & 7 & 8 & 7 & 8 & 9 & 10 & 10 \\
\hline $\begin{array}{l}\text { Number of visited } \\
\text { events per resident }\end{array}$ & 1.91 & 0.19 & 1.18 & 1.33 & 1.40 & 1.19 & 1.00 & 1.63 & 0.79 \\
\hline $\begin{array}{c}\text { Visitors' comfort } \\
\text { conditions, points }[5,10]\end{array}$ & 7 & 8 & 6 & 8 & 7 & 8 & 8 & 10 & 10 \\
\hline $\begin{array}{c}\text { Building energy performance, } \\
\text { points }[5,10]\end{array}$ & 8 & 8 & 8 & 8 & 9 & 8 & 8 & 9 & 9 \\
\hline $\begin{array}{l}\text { Environmental impact of } \\
\text { arena's activities, points }[5,10]\end{array}$ & 6 & 7 & 6 & 8 & 7 & 8 & 8 & 10 & 8 \\
\hline $\begin{array}{l}\text { Innovative technologies } \\
\text { employed, points }[5,10]\end{array}$ & 6 & 7 & 7 & 8 & 7 & 8 & 8 & 10 & 9 \\
\hline $\begin{array}{l}\text { Investment rate, } \\
\text { EUR per resident }\end{array}$ & 246 & 6 & 240 & 321 & 187 & 164 & 98 & 159 & 37 \\
\hline $\begin{array}{c}\text { Impact on relevant } \\
\text { business, points }[5,10]\end{array}$ & 7 & 6 & 6 & 7 & 7 & 7 & 8 & 9 & 8 \\
\hline $\begin{array}{c}\text { Impact on urban } \\
\text { development, points }[5,10]\end{array}$ & 7 & 6 & 7 & 7 & 8 & 8 & 8 & 10 & 9 \\
\hline
\end{tabular}

Once the set of evaluation criteria is established Multi-Criteria Decision Analysis can be applied to examine the problem of evaluating a discrete set of alternatives for investment into multi-functional arenas.

\section{Results and Discussion}

Most of the MCDM methods need the criteria weights, which can be determined by pairwise comparison method Analytic Hierarchy Process or ranking expertise method. Therefore, the weights of the criteria are calculated according to the judgments of experts.

\subsection{Weights of Developed Evaluation Criteria}

In order to establish the proper set of variables needed for investment assessment, the criteria and their corresponding relative levels of importance have to be evaluated. Such subjective weighting of established criteria was determined by using AHP as a subjective approach. AHP is one of the most widely used methods in various fields of research that provides means to optimize decision-making from a quantitative analysis and minimize impacts related to the use of purely qualitative methods [50].

Information about subjective weighting of developed criteria was gathered through pairwise comparisons questionnaire carried out in 2014. The questionnaire was issued to 28 experts; the major groups of respondents were managers and operators of multi-functional arenas (38\%), environmental 
consultants (21\%), researchers and academics, real estate and civil engineering professionals (21\%) and community representatives $(20 \%)$.

Table 4 shows the weighting assigned to the proposed investment evaluation criteria obtained from the pairwise evaluation. As can be seen from the weighting assignment results, the economic aspect, representing over $42 \%$ of the total, is considered more important than the environmental aspect, representing over $36 \%$, and the social aspect, representing over $21 \%$.

Table 4. Weights of evaluation criteria.

\begin{tabular}{ccc}
\hline Criteria & Subjective weight, $\%$ & Weighting by sustainability aspects \\
\hline Accessibility of arenas & 5.44 & \\
Number of visited events per resident & 7.06 & Social aspect $-21.41 \%$ \\
Visitors' comfort conditions & 8.91 & \\
\hline Building energy performance & 9.61 & \\
Environmental impact of arena's activities & 11.34 & Environmental aspect $-36.34 \%$ \\
Innovative technologies employed & 15.39 & \\
\hline Investment rate & 14.35 & Economic aspect $-42.25 \%$ \\
Impact on relevant businesses & 13.54 & \\
Impact on urban development & 14.36 & \\
\hline
\end{tabular}

In the context of real estate investment sustainability evaluation, several criteria of multi-functional arenas are of particular importance; these include employment of innovative technologies during construction and operation, investment rate, impact on relevant business and impact on urban development. In relation to the economic aspects the criteria "impact on urban development" and "investment rate" were ranked almost at the same importance within subjective weight of $14.36 \%$ and $14.35 \%$, and more important than the criterion "impact on relevant business", with significance of $13.54 \%$. Employment of innovative technologies during construction and operation, which is represented by $15.39 \%$, in relation to the environmental aspects, holds priority over other criteria. Visitors' comfort conditions, represented by $8.91 \%$, were considered the most important criterion in relation to the social aspects.

After the weights of the criteria were calculated, the concordance of expert judgments was verified. It showed the sufficient coherence of the invited experts' preferences and adequate use of their extensive knowledge.

\subsection{Evaluation of Investments into Multi-Functional Arenas Based on Sustainability Aspects}

Multi-criteria analysis of selected multi-functional sports and entertainment arenas investment alternatives was performed applying TOPSIS. The basic concept of TOPSIS is that the selected alternative should have the shortest distance from the ideal solution and the longest distance from the negative-ideal solution; and the benefits are that the only required judgments are weights of evaluation criteria, while relative distances depend on the weights and on the range of alternatives themselves [61].

According to the calculated separation measures from negative ideal and positive ideal solutions, the rate of the relative closeness to the ideal solution was established. Almost all suggested criteria, representing social, environmental and economic aspects, are expected to reach their maximum values, 
while only criterion "Investment rate" is targeted to the minimum. The relative closeness of the investment alternatives to the ideal solution is given in Table 5.

Table 5. Relative closeness and rank of investment alternatives.

\begin{tabular}{cccccccccc}
\hline \multirow{2}{*}{ Ranking } & \multicolumn{10}{c}{ Arenas } \\
\cline { 2 - 12 } & $\mathbf{X 1}$ & $\mathbf{X 2}$ & $\mathbf{X 3}$ & $\mathbf{X 4}$ & $\mathbf{X 5}$ & $\mathbf{X 6}$ & $\mathbf{X 7}$ & $\mathbf{X 8}$ & $\mathbf{X 9}$ \\
\hline Relative closeness & 0.32 & 0.43 & 0.23 & 0.30 & 0.42 & 0.49 & 0.59 & 0.81 & 0.75 \\
Rank & 7 & 5 & 9 & 8 & 6 & 4 & 3 & 1 & 2 \\
\hline
\end{tabular}

The established rates of the relative closeness to the ideal solution provide the basis for the sustainability categorization, assigned to one set out in LEED, BREEAM and SBTool [45]. Multi-functional arenas' sustainability categories are presented in Table 6.

Arenas as public buildings, serving community interests, are not considered as the real estate development objects of high financial profitability. However, taking into consideration the limited financial resources of the municipalities, which are the owners of the majority of arenas, the social-economic benefit/cost ratio plays an important role for the integrated performance assessment. Furthermore, the municipal subsidies granted to the multi-functional arenas are the money of the same taxpayers', who's recreational needs sports and entertainment venues are dedicated to meet. Annual financial subsidy rates per resident are presented in Table 7 .

Table 6. Sustainability categorization for multi-functional arenas.

\begin{tabular}{ccc}
\hline Categories of sustainability & Investment alternative & Rate \\
\hline & X3 & $23 \%$ \\
Towards sustainability $(0 \%-49 \%)$ & X4 & $30 \%$ \\
& X1 & $32 \%$ \\
Sustainable (50\%-79\%) & X2 & $42 \%$ \\
In search of new paradigms $(80 \%-100 \%)$ & X6 & $43 \%$ \\
& X7 & $49 \%$ \\
& X8 & $59 \%$ \\
\end{tabular}

Table 7. Annual subsidies for multi-functional arenas.

\begin{tabular}{cccccccccc}
\hline \multirow{2}{*}{ Financial criteria } & $\mathbf{X 1}$ & $\mathbf{X 2}$ & $\mathbf{X 3}$ & $\mathbf{X} 4$ & $\mathbf{X 5}$ & $\mathbf{X 6}$ & $\mathbf{X 7}$ & $\mathbf{X 8}$ & $\mathbf{X 9}$ \\
\cline { 2 - 9 } & 3 & - & 2 & 6 & 5 & 2 & - & 2 & - \\
\hline $\begin{array}{c}\text { Annual amount of subsidies } \\
\text { per resident, EUR }\end{array}$ & 3 & & & &
\end{tabular}

Consequently, the aggregated score for various investment alternatives can be established considering both sustainability and financial issues (see Table 8). The developers are encouraged to employ the overall ranking approach, while evaluating possible investment into public property options of new real estate development. 
Table 8. Overall evaluation of investment into multi-functional arenas.

\begin{tabular}{cccccccccc}
\hline Ranking & \multicolumn{1}{c}{ Arenas } \\
\cline { 2 - 10 } & $\mathbf{X 1}$ & $\mathbf{X 2}$ & $\mathbf{X 3}$ & $\mathbf{X 4}$ & $\mathbf{X 5}$ & $\mathbf{X 6}$ & $\mathbf{X 7}$ & $\mathbf{X 8}$ & $\mathbf{X 9}$ \\
\hline $\begin{array}{c}\text { Ranking based on } \\
\text { sustainability aspects }\end{array}$ & 7 & 5 & 9 & 8 & 6 & 4 & 3 & 1 & 2 \\
\hline $\begin{array}{c}\text { Ranking based on } \\
\text { financial performance }\end{array}$ & 5 & 1 & 4 & 7 & 6 & 2 & 1 & 3 & 1 \\
\hline Aggregated rank & 12 & 6 & 13 & 15 & 12 & 6 & 4 & 4 & 3 \\
\hline Overall ranking & $\mathbf{4}$ & $\mathbf{3}$ & $\mathbf{5}$ & $\mathbf{6}$ & $\mathbf{4}$ & $\mathbf{3}$ & $\mathbf{2}$ & $\mathbf{2}$ & $\mathbf{1}$ \\
\hline
\end{tabular}

\section{Conclusions}

The review of scientific literature revealed that, despite extended efforts to evaluate the sustainability aspects of the real estate development, very few attempts have been presented that pursue integrating and balancing the investors and real estate developers' responsibility for the local community, regional economy, and environmental problems with their financial expectations.

The Model for Real Estate Investment Evaluation Based on Sustainable Development Aspects developed by the authors incorporates the systematic components affecting the development of sustainable built environment from real estate project idea formation to the end of the life cycle as well as enables evaluating the overall investment effectiveness of real estate development in light of sustainable development. This approach raises awareness amongst owners, occupants, and investors to justify the design, construction and operation solutions, while preparing the feasibility study of new real estate development.

The model was verified by applying it to the case study of Lithuanian sports and entertainment arenas. Priority ranking results of nine multi-functional arenas' sustainability performance approved the proposed approach of real estate investment evaluation based on sustainable development aspects.

Assessment of Lithuanian sports and entertainment arenas by the Model for Real Estate Investment Evaluation Based on Sustainable Development Aspects revealed the sustainability advantages of three Lithuanian arenas, whilst the analysis of the financial performance disclosed that positive sustainability effects the owner's and operator's monetary liabilities.

\section{Acknowledgments}

The authors gratefully acknowledge the respondents who participated in the survey.

\section{Author Contributions}

All authors contributed equally to this work. Tautvydas Baltramonaitis developed the model and conducted the expert interviews as well as initial quantitative and qualitative data collection. Rasa Apanavičienè led the development of the methodology for this research. Ala Daugèlienè revised and expanded the initial data and performed multi-criteria analysis. Rasa Apanavičienè and Ala Daugèlienè wrote the initial draft of this paper. Vida Maliene was responsible for the final paper revision and improvement. All authors discussed the results and implications, and commented on the manuscript at all stages. 


\section{Conflicts of Interest}

The authors declare no conflict of interest.

\section{References and Notes}

1. Ober-Haus Real Estate Advisors. Available online: http://www.ober-haus.lt (accessed on 1 February 2015).

2. Real estate market report 2015. Available online: http://www.ober-haus.lt/wp-content/ uploads/2015/03/Ober-Haus-Market-Report-Baltic-States-2015.pdf (accessed on 1 March 2015).

3. Sorainen. Available online: http://www.sorainen.com (accessed on 1 March 2015).

4. BREEAM New Construction. Technical Manual SD5073, 2011. Available online: http://www.breeam.org/breeamGeneralPrint/breeam_non_dom_manual_3_0.pdf (accessed on 22 November 2014).

5. LEED v4 BD+C: New Construction, 2013. Available online: http://www.usgbc.org/credits/ newconstruction/v4 (accessed on 22 November 2014).

6. DGNB System fürGebäude, 2014. Available online: http://www.dgnb-system.de/de/system/ kriterien (accessed on 15 May 2014).

7. CASBEE for Building (New Construction). Available online: http://www.ibec.or.jp/CASBEE/ english/download.htm (accessed on 15 May 2014).

8. HQE. Assessment Scheme for the Environmental Performance of Buildings - "Non-residential buildings"-Version 7 June 2012. Available online: http://www.certivea.fr/home (accessed on 15 May 2014).

9. SBTool 2012. Available online: http://www.iisbe.org/sbtool-2012 (accessed on 15 May 2014).

10. Vesta Consulting. Available online: http://www.vestaconsulting.lt/en.html (accessed on 15 December 2014).

11. Republic of Lithuania Law on Environmental Impact Assessment of the Proposed Economic Activity. No I-1495, 15 August 1996. (As last amended on 30 June 2008-No X-1654) Vilnius.

12. The Lithuanian Law on Construction. Available online: http://www3.lrs.lt/pls/inter3/ dokpaieska.showdoc_1?p_id=454053 (accessed on 15 May 2014).

13. Methodology for investment projects seeking for financial assistance under European Structural Funds and/or State Budget; amended on 31 December 2014 No 2014/8-337 by Central Project Management Agency. Available online: http://www.esinvesticijos.lt/lt/dokumentai/ investicijuprojektu-kuriems-siekiama-gauti-finansavima-is-europos-sajungos-strukturines-paramos-ir-arvalstybes-biudzeto-lesu-rengimo-metodika (accessed on 10 January 2015).

14. Methodology for the quality review of optimal alternative selection for project implementation; amended on 13 October 2014 No 13 by Managing Authority of EU Structural Funds in 2014-2020. Available online: http:/www.esinvesticijos.lt/lt/dokumentai/optimalios-projekto-igyvendinimoalternatyvos-pasirinkimo-kokybes-vertinimo-metodika (accessed on 17 November 2014).

15. ISO TC59 SC 17 Sustainability in buildings and civil engineering works. Available online: http://www.iso.org/iso/standards_development/technical_committees/other_bodies/iso_technical_ committee.htm?commid=322621 (accessed on 20 April 2015). 
16. CEN Technical Committee 350 Sustainability of Construction Works. Available online: http://www.cen.eu/cen/Sectors/Sectors/Construction/SustainableConstruction/Pages/CEN_TC350. aspx (accessed on 20 April 2015).

17. SuPerBuilding. Sustainability and performance assessment and benchmarking of building. Available online: http://www.vtt.fi/inf/pdf/technology/2012/T72.pdf (accessed on 20 April 2015).

18. OPEN HOUSE. Benchmarking and mainstreaming building sustainability in the UE based on transparency and openness from model to implementation. Available online: http://www.openhousefp7.eu/assets/files/D1.5_Baseline_model_and_assessment_methodology.pdf (accessed on 20 April 2015).

19. Lowe, C.; Ponce, A. UNEP-FI /SBCI'S financial \& sustainability metrics report. An international review of sustainable building performance indicators \& benchmarks. Available online: http://www.unepfi.org/fileadmin/documents/metrics_report_01.pdf (accessed on 20 March 2014).

20. Sustainable Construction: Realising the Opportunities for Built Environment Professionals. Available online: http://www.rics.org/Global/Europe\%20publications/Sustainable\%20Construction_ Realising\%20the\%20Opportunities\%20(Oct\%202013).pdf (accessed on 20 March 2014).

21. Sustainability Metrics. Translation and Impact on Property Investment and Management. A report by the Property Working Group of the United Nations Environment Programme Finance Initiative. Available online: http://www.unepfi.org/fileadmin/documents/UNEPFI_SustainabilityMetrics_ Web.pdf (accessed on 15 December 2014).

22. Principles Responsible Investment for Building responsible property portfolios. A review of current practice by UNEP FI and PRI signatories. UNIEP, 2008. Available online: http://www.unepfi.org/ fileadmin/documents/building_responsible_property_portfolios.pdf (accessed on 20 March 2014).

23. Sustainable Property Investment \& Management Key Issues \& Major Challenges. Available online: http://www.joinricsineurope.eu/uploads/files/Sustainable\%20Property\%20Investment $\% 20$ and $\% 20$ management $\% 20$ RICS\%20sept $\% 2008$.pdf (accessed on 20 March 2014).

24. Principles of responsible investing. Available online: http://www.unpri.org (accessed on 20 April 2015).

25. Zielenbach, S. Measuring the impact of community development. Available online: http://www.bostonfed.org/commdev/c\&b/2004/fall/measuring.pdf (accessed on 20 April 2015).

26. Castellani, V.; Sala, S. Sustainability Indicators Integrating Consumption Patterns in Strategic Environmental Assessment for Urban Planning. Sustainability 2013, 5, 3426-3446.

27. Zhang, X.; Wu, Y.; Skitmore, M.; Jiang, S. Sustainable infrastructure projects in balancing urban-rural development: Towards the goal of efficiency and equity. J. Cleaner Prod. 2014, doi:10.1016/j.jclepro.2014.09.068

28. McDonald, S.; Malys, N.; Maliene, V. Urban regeneration for sustainable communities: A case study. Technol. Econ. Dev. Econ. 2009, 15, 49-59.

29. Boz, M.; El-adaway, I. Creating a Holistic Systems Framework for Sustainability Assessment of Civil Infrastructure Projects. J. Constr. Eng. Manag. 2014, doi:10.1061/(ASCE)CO.19437862.0000911.

30. Shen, L.; Wu, Y.; Zhang, X. Key Assessment Indicators for the Sustainability of Infrastructure Projects. J. Constr. Eng. Manag. 2011, 137, 441-451. 
31. Adetola, A.; Goulding, J.; Liyange, C. Collaborative engagement approaches for delivering sustainable infrastructure projects in the AEC sector: A Review. Int. J. Constr. Supply Chain Manag. 2011, 1, 1-24.

32. Jakimavičius, M.; Burinskienè, M. Multiple criteria assessment of a new tram line development scenario in Vilnius City public transport system. Transport 2013, 28, 431-437

33. Griškevičiūtè-Gečienè, A.; Burinskienė, M. Towards creating the assessment methodology for urban road transport development projects. Technol. Econ. Dev. Econ. 2012, 18, 651-671.

34. Shari, Z.; Soebarto, V. Investigating sustainable practices in the Malaysian office building developments. Constr. Innov. 2014, 14, 17-37.

35. Prochorskaite, A.; Maliene, V. Health, well-being and sustainable housing. Int. J. Strateg. Prop. Manag. 2013, 17, 44-57.

36. Yates, J. Design and Construction for Sustainable Industrial Construction. J. Constr. Eng. Manag. 2014, 140, doi:10.1061/(ASCE)CO.1943-7862.0000673

37. Xia, B.; Skitmore, M.; Wu, P.; Chen, Q. How Public Owners Communicate the Sustainability Requirements of Green Design-Build Projects. J. Constr. Eng. Manag. 2014, 140, doi:10.1061/ (ASCE)CO.1943-7862.0000879.

38. Vatalis, K.I.; Manoliadis, O.; Charalampides, G.; Platias, S.; Savvidis, S. Sustainability Components Affecting Decisions for Green Building Projects. Procedia Econ. Financ. 2013, 5, 747-756.

39. Vaiškūnaitè, R.; Mieriauskas, P.; Špakauskas, V. Biodiversity impacts assessment in road development in Lithuania. Transport 2012, 27, 187-195.

40. Valdes-Vasquez, R.; Klotz, L. Social Sustainability Considerations during Planning and Design: Framework of Processes for Construction Projects. J. Constr. Eng. Manag. 2013, 139, 80-89.

41. Mostafa, M.; El-Gohary, N. Stakeholder-Sensitive Social Welfare-Oriented Benefit Analysis for Sustainable Infrastructure Project Development. J. Constr. Eng. Manag. 2014, 140, doi:10.1061/ (ASCE)CO.1943-7862.0000788

42. Snieška, V.; Šimkūnaitè, I. Socio-Economic Impact of Infrastructure Investments. Eng. Econ. (Inzinerine Ekonomika) 2009, 3, 16-25.

43. Wang, N.; Wei, K.; Sun, H. Whole Life Project Management Approach to Sustainability. J. Manag. Eng. 2014, 30, 246-255.

44. Swarup, L.; Korkmaz, S.; Riley, D. Project Delivery Metrics for Sustainable, High-Performance Buildings. J. Constr. Eng. Manag. 2011, 137, 1043-1051.

45. Bragança, L.; Mateus, R.; Koukkari, H. Building Sustainability Assessment. Sustainability 2010, 2, 2010-2023.

46. Markelj, J.; KitekKuzman, M.; Grošelj, P.; Zbašnik-Senegačnik, M. A Simplified Method for Evaluating Building Sustainability in the Early Design Phase for Architects. Sustainability 2014, 6, 8775-8795.

47. Waas, T.; Hugé, J.; Block, T.; Wright, T.; Benitez-Capistros, F.; Verbruggen, A. Sustainability Assessment and Indicators: Tools in a Decision-Making Strategy for Sustainable Development. Sustainability 2014, 6, 5512-5534.

48. Bragança, L.; Vieira, S.M.; Andrade, J.B. Early Stage Design Decisions: The Way to Achieve Sustainable Buildings at Lower Costs. Sci. World J. 2014, doi:10.1155/2014/365364. 
49. Wong, J.K.-W.; Kuan, K.-L. Implementing 'BEAM Plus' for BIM-based sustainability analysis. Autom. Constr. 2014, 44, 163-175.

50. VillarinhoRosa, L.; Haddad, A.N. Building Sustainability Assessment throughout Multicriteria Decision Making. J. Constr. Eng. 2013, 2013, Article 578671.

51. Azhar, S.; Carlton, W.A.; Olsen, D.; Ahmad, I. Building information modelling for sustainable design and LEED rating analysis. Autom. Constr. 2011, 20, 217-224.

52. Luetzkendorf, T.; Fan, W.; Lorenz, D. Engaging financial stakeholders: Opportunities for a sustainable built environment. Build. Res. Inf. 2011, 39, 483-503.

53. Deng, Y.; Wu, J. Economic returns to residential green building investment: The developers' perspective. Reg. Sci. Urban Econ. 2014, 47, 35-44.

54. Trowbridge, M.J.; Pickell, S.G.; Pyke, C.R.; Jutte, D.P. Building Healthy Communities: Establishing Health and Wellness Metrics for Use within the Real Estate Industry. Health Affairs 2014, 33, 1923-1929.

55. Rakhshan, K.; Friess, W.A.; Tajerzadeh, S. Evaluating the sustainability impact of improved building insulation: A case study in the Dubai residential built environment. Build. Environ. 2013, 67, 105-110.

56. Eichholtz, P.; Kok, N.; Yonder, E. Portfolio greenness and the financial performance of REITs. J. Int. Money Finance 2012, 31, 1911-1929.

57. Knoepfel, P.; Csikos, P.; Gerber, J.D. Transformation of the Role of the State and of Corporate Land Owners in Urban Development Processes in Light of Sustainable Development. Politische Vierteljahresschrift 2012, 53, 414-443.

58. Rudžianskaitè-Kvaraciejienè, R.; Apanavičienė, R.; Gelžinis, A. Modelling the effectiveness of PPP road infrastructure projects by applying random forests. J. Civil Eng. Manag. 2015, 21, 290-299.

59. Velasquez, M.; Hester, P.T. An Analysis of Multi-Criteria Decision Making Methods. Int. J. Oper. Res. 2013, 10, 56-66.

60. Aruldoss, M.; Lakshmi, T.M.; Venkatesan, V.P. A Survey on Multi Criteria Decision Making Methods and Its Applications. Am. J. Inf. Syst. 2013, 1, 31-43.

61. Huang, I.; Keisler, J.; Linkov, I. Multi-Criteria Decision Analysis in Environmental Science: Ten Years of Applications and Trends. Sci. Total Environ. 2011, 409, 3578-3594.

62. Antucheviciene, J.; Zakarevicius, A.; Zavadskas, E.K. Measuring congruence of ranking results applying particular MCDM methods. Informatica 2011, 22, 319-338.

63. Seifried, C.; Clopton, A.W. An alternative view of public subsidy and sport facilities through social anchor theory. City Culture Soc. 2013, 4, 49-55.

64. Liu, Y.; Zhao, G.; Wang, S. Case Study VI—The National Stadium BOT Project for Beijing 2008 Olympic Games. In Public —Private Partnership in Infrastructure Development: Case Studies from Asia and Europe; Bauhaus-Universität Weimar: Weimar, Germany, 2009; pp. 130-152.

65. Liu, T.; Wilkinson, S. Large-scale public venue development and the application of Public_-Private Partnerships (PPPs). Int. J. Project Manag. 2013, 32, 88-100.

66. Kellison, T.B.; Mondello, M.J. Organisational perception management in sport: The use of corporate pro-environmental behaviour for desired facility referenda outcomes. Sport Manag. Rev. 2012, 15, 500-512. 
67. Lasley, S.; Turner, J. Home run or strikeout: The dynamics of public opinion on new sports facilities. Soc. Sci. J. 2010, 47, 853-864.

68. Coates, D.; Humphreys, B.R. Proximity benefits and voting on stadium and arena subsidies. J. Urban Econ. 2006, 59, 285-299.

69. Grieve, J.; Sherry, E. Community benefits of major sport facilities: The Darebin International Sports Centre. Sport Manag. Rev. 2012, 15, 218-229.

70. Propheter, G. Are basketball arenas catalysts of economic development? J. Urban Affairs 2012, 34, 441-459.

71. Jones, C.; Munday, M.; Roche, N. Can regional sports stadia ever be economically significant? Reg. Sci. Policy Pract. 2010, 2, 63-78.

72. Ahlfeldt, G.; Maennig, W. Stadium Architecture and Urban Development from the Perspective of Urban Economics. Int. J. Urban Reg. Res. 2010, 34, 629-646.

73. Barghchi, M.; Omar, D.B.; Aman, S.M. Sports Facilities Development and Urban Generation. J. Soc. Sci. 2009, 5, 460-465.

74. Mallen, C.; Chard, C. "What could be" in Canadian sport facility environmental sustainability. Sport Manag. Rev. 2012, 15, 230-243.

75. Mallen, C.; Adams, L.; Stevens, J.; Thompson, L. Environmental sustainability in sport facility management: A Delphi study. Eur. Sport Manag. Q. 2010, 10, 367-389.

76. Koukiasa, M. Sustainable Facilities Management within Event Venues. Worldw. Hosp. Tour. Themes 2011, 3, 217-228.

77. Biggest Lithuanian arenas. Available online: http://www.topten.lt/didziausios-lietuvos-arenos/ (accessed on 15 September 2014).

78. Nine basketball arenas were built in Lithuania within the last five years for 400 million LTL. Available online: http://www.15min.lt/sportas/naujiena/krepsinis/lietuvos-krepsinio-arenos-23420053 (accesses on 15 September 2014).

79. What makes the arenas, established for basketball championship. Available online: http://www.lrt.lt/naujienos/kalba_vilnius/32/78505/kuo_gyvena_krepsinio_cempionatui_gausiai_s tatytos_arenos_(accessed on 15 December 2014).

80. Official website of Alytus Arena. Available online: http://www.asrc.lt/ (accessed on 15 September 2014).

81. Official website of Zalgiris Arena. Available online: http://zalgirioarena.lt/ (accessed on 15 September 2014).

82. Official website of Siemens Arena. Available online: http://www.siemens-arena.com/ (accessed on 15 September 2014).

83. Official website of Svyturys Arena. Available online: http://svyturioarena.lt/ (accessed on 15 September 2014).

84. Official website of Siauliai Arena. Available online: http://www.siauliuarena.lt/ (accessed on 15 September 2014).

85. Official website of Cido Arena. Available online: http://www.cidoarena.lt/ (accessed on 15 September 2014). 
86. Arenas of EuroBasket 2011: Pride of Lithuania. Available online: http://www.basketzone.lt/ naujienos/8672-eurobasket-2011-arenos-lietuvos-pasididiavimas-foto.html (accessed on 15 September 2014).

87. Official website of Vilnius Entertainment Arena. Available online: http://www.pramoguarena.lt/ (accessed on 15 September 2014).

88. Official website of Utena Arena. Available online: http://www.sportas.utena.lm.lt/ (accessed on 15 September 2014).

89. Official website of Kedainiai Arena. Available online: http://kedainiu-arena.lt/ (accessed on 15 September 2014).

(C) 2015 by the authors; licensee MDPI, Basel, Switzerland. This article is an open access article distributed under the terms and conditions of the Creative Commons Attribution license (http://creativecommons.org/licenses/by/4.0/). 